\title{
New species and new records of Dolichopodidae (Diptera) from Israel
}

\author{
Новые виды и новые указания Dolichopodidae (Diptera) \\ из Израимя
}

\author{
I.Ya. Grichanov ${ }^{1}$, A. Freidberg 2 \\ И.Я. Гричанов ${ }^{1}$ А. Фрайдберг ${ }^{2}$
}

\begin{abstract}
${ }^{1}$ All-Russian Institute of Plant Protection, Podbelskiy roadway, 3, St. Petersburg-Pushkin, 196608 Russia. E-mail: grichanov@mail.ru ${ }^{1}$ Всероссийский институт защиты растений, шоссе Подбельского, 3, Санкт-Петербург-Пушкин 196608, Россия.

${ }^{2}$ The Steinhardt Museum of Natural History, School of Zoology, Faculty of Life Sciences, Tel Aviv University, Tel Aviv 69978, Israel. Email: afdipter@post.tau.ac.il
\end{abstract}

KEY WORDS: Diptera, Dolichopodidae, Palaearctic Region, Israel, Hercostomus plagiatus species group, Condylostylus, new species, key.

КЛЮЧЕВЫЕ СЛОВА: Diptera, Dolichopodidae, Палеарктика, Израиль, группа видов Hercostomus plagiatus, Condylostylus, новые виды, определитель.

ABSTRACT: Two new species from Israel, Hercostomus kravchenkoi sp.n. and Hercostomus yefremovae sp.n., are described of the Hercostomus plagiatus species group differing from the other groups in the male segment 7 short, bare, with distinct tergum and sternum; hypopygium large, with small or without basiventral epandrial lobes near base of hypandrium; hypandrium mostly free, simple, fused to epandrium at extreme base; apicoventral epandrial lobes located rather distally, far from base of hypandrium. A key to species of the H. plagiatus group is provided. Hercostomus thraciensis Kechev et Negrobov, 2015, and Condylostylus longicornis (Fabricius, 1775) are recorded from the country for the first time. Photographs of Israeli specimens of $H$. kravchenkoi sp.n., H. yefremovae sp.n. and $H$. thraciensis are provided.

РЕЗЮМЕ. Описаны два новых вида из Израиля, Hercostomus kravchenkoi sp.n. и Hercostomus yefremovae sp.n. из группы видов Hercostomus plagiatus, отличающейся от других групп рода по короткому 7-му сегменту брюшка самцов, лишённому щетинок, разделённому на тергит и стернит; большой генитальной капсулой (гипопигием), редуцированными базовентральными отростками эпандрия около основания гипандрия; а также свободным, простым гипандрием, слившимся с эпандрием в его основании; апиковентральными отростками эпандрия, расположенными далеко от основания гипандрия. Приведён определитель группы видов H. plagiatus. Hercostomus thraciensis Kechev et Negrobov, 2015, и Condylostylus longicornis (Fabricius, 1775), впервые указаны для страны. Даны иллюстрации Hercostomus kravchenkoi sp.n., Hercostomus yefremovae sp.n. и H. thraciensis, собранных в Израиле.

\section{Introduction}

The genus Hercostomus Loew, 1857 has an extremely high diversity of mainly endemic species in the Holarctic Realm and Oriental Region, with nearly 500 species worldwide [Grichanov, 2017a]. Keys to traditional Palaearctic species groups of Hercostomus were composed by Negrobov et al. [2008, 2012], Negrobov, Nechay [2009a, b] and Selivanova et al. [2012]. Later seven species of the genus were described from western part of the Palaearctic Region, i.e. from Bulgaria, Golan Heights, Iran, Spain, Tajikistan and Turkey [Grichanov, 2015; Kechev, Negrobov, 2015; Naglis, Bartak, 2015; Negrobov et al., 2016; Tonguç et al., 2016; Kazerani et al., 2017; Naglis, Negrobov, 2017].

Treating the diverse collections of Tel Aviv University (Israel), we have found males and females of two undescribed dolichopodine species that can be associated with the enigmatic Hercostomus plagiatus species group, which strongly differs from the nominotypical $H$. longiventris species group [Pollet, 1993; Grichanov, 2015]. Recent molecular analyses have attempted to shed light on Dolichopodinae relationships, including some Hercostomus species groups. Hercostomus plagiatus (Loew, 1857) and H. verbekei Pollet 1993 have been included in molecular analyses of the subfamily using fragments of mitochondrial COI, ribosomal $12 \mathrm{~S}$ rDNA and 16S rDNA, where these species resolve rather distant from H. longiventris (Loew, 1857) and

How to cite this article: Grichanov I.Ya., Freidberg A. 2018. New species and new records of Dolichopodidae (Diptera) from Israel // Russian Entomol. J. Vol.27. No.3. P.299-306. doi: 10.15298/rusentj.27.3.12 
some other Hercostomus groups and appear closer to Gymnopternus Loew, 1857 [Bernasconi et al., 2007] or even Tachytrechus Haliday, 1851 [Pollet et al., 2010].

Grichanov [2015] has described H. golanensis from that group and supposed that some other species of the genus Hercostomus could be included in the H. plagiatus group; among those species are $H$. libanicola Parent, 1933, and H. cyprius Parent, 1937 from the Mediterranean Region, H. pokivajlovi Maslova et Negrobov, 2011, from Tajikistan, and H. additus Parent, 1926, from the Oriental part of China. Kazerani et al. [2017] have described H. albicoxa from Iran, apparently a member of the $H$. plagiatus group, and found great similarity of this species to $H$. convergens Loew, 1908, and H. insularum Becker, 1917.

In the present paper, two new species, Hercostomus kravchenkoi sp.n., and Hercostomus yefremovae sp.n. from Israel are described and illustrated. A key to the eleven known West Palaearctic species of the H. plagiatus species group is also presented, and characters of the group are discussed. In addition, Hercostomus thraciensis Kechev et Negrobov, 2015, and Condylostylus longicornis (Fabricius, 1775) are recorded from the country for the first time.

\section{Material and methods}

The holotypes and paratypes of the new species and other material examined are housed at the School of Zoology, Tel Aviv University, Israel (SMNH).

Specimens were studied and photographed with a ZEISS Discovery V-12 stereo microscope and an AxioCam MRc5 camera. Morphological terminology and abbreviations follow Grichanov, Brooks [2017]. The lengths of the podomeres are given in millimetres. Body length is measured from the base of the antenna to the tip of epandrium. Male genitalia were macerated in $10 \%$ $\mathrm{KOH}$. The figures showing the hypopygium in lateral view (i.e., Fig. 4) is oriented as it appears on the intact specimen, with the morphologically ventral surface of the genitalia facing upwards, dorsal surface downwards, anterior end facing right and posterior end facing left.

\section{Systematics}

\section{Hercostomus plagiatus species group}

DIAGNOSIS. This diagnosis is based on males and females of the 11 included species.

Body about $4 \mathrm{~mm}$ long, wing slightly shorter or slightly longer; body robust, usually dark metallic; head higher than wide; face gradually narrowed towards palpi; clypeus small, slightly bulging in both sexes, not reaching ventral margin of eyes; palpus and proboscis small; vertical setae stronger than postverticals; antenna with simple antennomeres, located at dorsal quarter of head; scape setose dorsally, with pointed apicoventral process; pedicel with medial triangular projection; postpedicel rounded-triangular, with mid-dorsal stylus; arista-like stylus usually short-pubescent (but long-pubescent in $H$. golanensis); pleural surface in front of posterior spiracle bare; mesonotum without distinct dark spot above notopleuron; 1 strong and 1-2 fine postpronotals, 1 strong humeral, 2-3 presutural, 1 sutural, 2 notopleural, 2 supraalar, and 1 postalar bristles well developed; 6 pairs of strong dorsocentral bristles slightly decreasing in length anteriorly; acrostichals biserial; anterior slope of mesonotum with dense hairs; propleuron with group of hairs above and 1 strong bristle below; all legs relatively short, with rather strong and long major bristles on at least mid and hind tibiae; hind coxa with 1 strong lateral seta at middle; one strong posterior to posteroventral preapical seta on mid femur; mid and hind femora moderately broad, with one preapical anterior bristle; mid tibia with strong ventral bristles; hind tibia with only fine ventral setae; tarsi simple; hind basitarsus distinctly shorter than next tarsomere; wing with veins $\mathrm{R}_{4+5}$ and $\mathrm{M}_{1}$ usually straight and weakly convergent; abdominal sterna 3 and 4 strongly sclerotized; tergum 6 mostly concealed, bare; segment 7 short, bare, with distinct tergum and sternum; hypopygium large, with small or without basiventral epandrial lobes near base of hypandrium; hypandrium mostly free, fused to epandrium at extreme base; apicoventral epandrial lobes arising rather distally, far from base of hypandrium; anteroventral part of postgonite not developed; posterodorsal portion poorly developed, hornlike, slightly curved ventrally, swollen at base, with reduced lateral lobes; surstylus bilobate.

\section{Hercostomus kravchenkoi Grichanov, sp.n.} Figs 1-7.

MATERIAL. Holotype $0^{7}$, Israel: Herzliyya, Hill, $32^{\circ} 11^{\prime} \mathrm{N}$

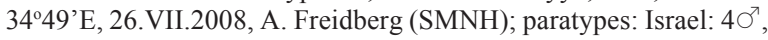
Herzliyya, Hill, $32^{\circ} 11^{\prime} \mathrm{N} 34^{\circ} 49^{\prime} \mathrm{E}, 17$.V.2008, 26.VII.2008, 30.VIII.2008, A. Freidberg; $620^{7}$, 179, Herzliyya, Malaise trap, 23.VI-19.VIII.1981, 5.VI-24.VIII.1982, A. Freidberg; 29, Herzliyya, 28.VIII.1977, F. Kaplan; 107, Tel Dan, 25.VIII.1983, I. Yarom; 1, Haifa, 21.VIII.1976, A. Freidberg (SMNH).

DESCRIPTION. Male (Fig. 1). Head. Slightly wider than high; antenna mostly yellow, distal half of postpedicel brown, arista-like stylus brown-black (Fig. 2); postpedicel rounded, as long as high, with short hairs; stylus mid-dorsal, $2.5 \mathrm{X}$ longer than antennomeres combined; distal segment of stylus with short hairs; length ratio of scape to pedicel (inner view) to postpedicel to stylus (segments 1 and 2), 0.07/0.08/ 0.17/0.07/0.67; frons black with greenish reflection, grey pollinose, slightly narrowed towards antennae, as wide as high, with distinct dot-like depression in middle of lower part; eyes finely haired, almost holoptic; face densely white pollinose; ratio of height to width under antennae to width at clypeus, 0.37/0.1/0.02; clypeus small; palpus small, yellow, with few yellow hairs and 1 black seta; proboscis short, yellow, with yellow hairs; all postocular setae yellow.

Thorax. All setae black; pronotum pubescent, with black hairs; mesonotum blue-green, weakly grey pollinose; 6 dorsocentral setae, about 10 acrostichals, short, biserial, reaching $5^{\text {th }}$ pair of dorsocentrals; pleura mainly dark, with grey pruinosity, in front of posterior spiracle bare; metapleuron yellow, bare; scutellum blue-green, with 2 strong medial setae and 2 minute lateral setae.

Legs. Entirely yellow, hairs and setae black; coxae yellow; all tarsi simple; foreleg with coxa bearing numerous 

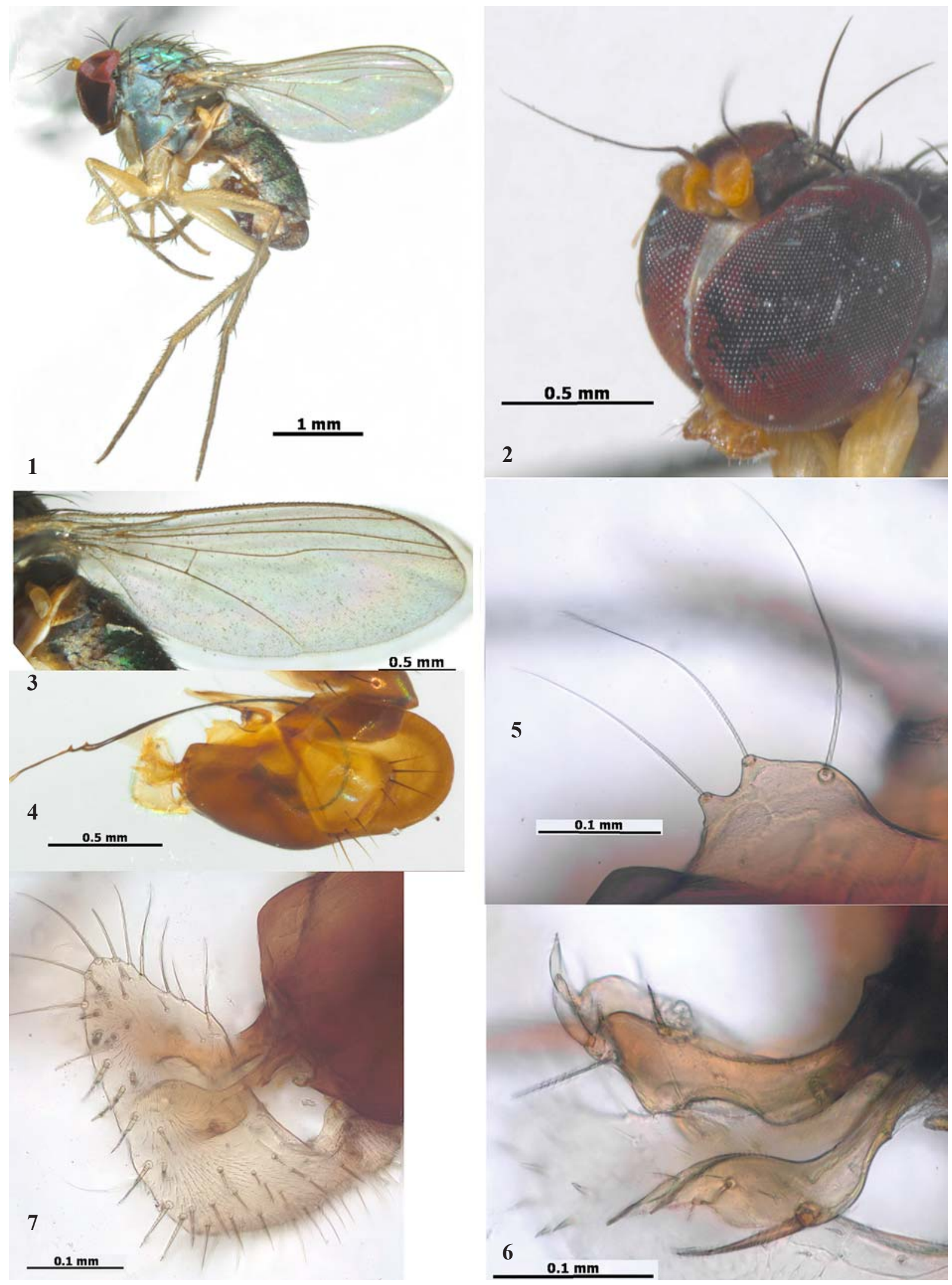

Figs 1-7. Hercostomus kravchenkoi Grichanov, sp.n., male: 1 - habitus; 2 - head; 3 - wing; 4 - hypopygium, lateral view; 5 apicoventral epandrial lobe; 6 - surstylus; 7 - cercus.

Pис. 1-7. Hercostomus kravchenkoi Grichanov, sp.n., самец: 1 - внешний вид; 2 - голова; 3 - крыло; 4 - гипопигий, сбоку; 5 - апиковентральная лопасть эпандрия; 6 - сурстиль; 7 - церка. 
yellow hairs anteriorly and 3 strong black setae apically, fore femur with preapical posterior seta, fore tibia with 2 anterodorsal, 2 posterodorsal, 2-3 apical short setae, no anterodorsal comb-like row of setae, no long apicoventral seta; midleg with coxa bearing some black hairs and setae apically, mid femur with 1 strong anterior preapical seta and 1 fine posteroventral preapical seta, mid tibia with 3 anterodorsal, 3 posterodorsal, 1 anteroventral and 5 apical bristles; hind leg with coxa bearing 1 strong seta at middle, hind femur with 1 anterior preapical bristle at apical quarter, hind tibia with 3 anterodorsal, 3 posterodorsal, 3 apical bristles; hind basitarsus distinctly shorter than next tarsomere, with $2-3$ short ventral setae. Tibia and tarsomere (from first to fifth) length ratio: fore leg: 42/18/7/4/3/4, mid leg: 38/15/9/8/4/3, hind leg: $37 / 11 / 12 / 9 / 4 / 5$.

Wing (Fig. 3). 3 times longer than wide; membrane hyaline, veins brown; costa simple, with short black setae dorsally; $\mathrm{R}_{1}$ and $\mathrm{R}_{2+3}$ almost straight; $\mathrm{R}_{4+5}$ slightly convex anteriorly; $\mathrm{M}$ with weak sinuation before middle of distal section; $\mathrm{R}_{4+5}$ and $M_{1}$ subparallel in distal quarter of wing; $M$ joining costa before wing apex; ratio of costal section between $\mathrm{R}_{2+3}$ and $\mathrm{R}_{4+5}$ to that between $\mathrm{R}_{4+5}$ and $\mathrm{M}_{1}: 38 / 9$, distal part of $\mathrm{M}_{4}^{2+3} 5.5 \mathrm{X}$ longer than $\mathrm{dm}-\mathrm{m}$; anal vein distinct; anal angle obtuse; lower calypter yellow with black cilia; halter yellow.

Abdomen. Bluish-green and shiny dorsally, with terga 15 broadly yellow ventrally, with black hairs and long marginal setae; $6^{\text {th }}$ tergum bare; $7^{\text {th }}$ segment black-brown, bare, with well developed tergum and sternum; $8^{\text {th }}$ segment pear-like, yellow, with black cilia dorsally.

Male genitalia (Figs 4-7). Epandrium black, ovate, flattened basally, as long as terga 3-6 combined; appendages mainly yellow; hypandrium mostly free, fused to epandrium at extreme base, straight, nearly reaching apex of epandrium; phallus thin and long; basiventral epandrial lobes small, symmetrical; apicoventral epandrial lobe (Fig. 5) arising rather distally, prominent, bearing 3 setae; anteroventral part of postgonite not developed; posterodorsal portion well developed, horn-like, slightly curved ventrally, thick, with reduced lateral lobes; surstylus (Fig. 6) bilobed, ventral lobe elongate-ovate, with middorsal emargination, with few apical and subapical setae and thick apical spine, dorsal lobe thin, expanded at middle, pointed at apex, slightly curved dorsally, with short apical setae and 1 strong basodorsal seta; cercus (Fig. 7) light yellow, crescent, higher than long, $1 / 8^{\text {th }}$ epandrium length, with row of short white marginal setae, without modified setae.

Measurements. Body length 3.2-3.4 mm, antenna length $1.0 \mathrm{~mm}$, wing length $3.1 \mathrm{~mm}$, wing width $1 \mathrm{~mm}$.

Female. Similar to male except lacking male secondary sexual characters. Face wider than in male, nearly as wide as postpedicel, slightly narrowed towards clypeus. Measurements. Body length $3.7 \mathrm{~mm}$; wing length $3.5 \mathrm{~mm}$.

ETYMOLOGY. The species is named after the Israeli and Russian entomologist Dr. Vasilii D. Kravchenko.

DIAGNOSIS. Face under antenna about half as wide as postpedicel height; eyes almost contiguous in middle of face; postpedicel rounded, as long as high; arista-like stylus shortpubescent, 2.5X longer than antennomeres combined; wing hyaline; wing veins $\mathrm{R}_{4+5}$ and $\mathrm{M}_{1}$ slightly convergent, subparallel in distal quarter of wing; dm-m located right behind level of $\mathrm{R}_{1}$; lower calypter with black setae; abdomen mainly dark with tergums yellow ventrally and segment 8 yellow; hypopygium with yellow crescent cercus without scale-like setae; hypandrium straight, nearly reaching apex of epandrium; apicoventral epandrial lobe broad, bearing 2 setae.

\section{Hercostomus yefremovae Grichanov, sp.n. Figs 8-16.}

MATERIAL. Holotype O', Israel: Tel Aviv, 26.III.1973, A. Freidberg (SMNH); paratypes: Israel: $2 \sigma^{7}, 1$, , Tel Aviv, 14.III.1973, 1.V.1973, 29.III.1974, A. Freidberg; 50', Tel Aviv, 2.IV.1971, 12.V.1971, 13.VI.1971, leg. Kugler; 10 $0^{\top}$, Baniass [Panyas], 8.IV.1971, 12.IX.1971, leg. Kugler; $10^{7}$, Tel Dan, 15.V.1981, A. Freidberg; $10^{7}$,Up. W. Faria [Nahal Tirza], 28.IV.1976, M. Kaplan; $40^{7}, 3$, Bteicha [Biq'at Bet Zayda], 14.III.1975, A. Freidberg; $50^{7}$, W. Kelt [Wadi Kelt], 25.III.1975, A. Freidberg; $10^{7}$,'Enot Zukim, 22.III.2008, A. Freidberg (SMNH).

DESCRIPTION. Male (Fig. 8). Head. Slightly wider than high (Fig. 9); antenna mostly yellow, distal half of postpedicel brown, arista-like stylus brown-black; postpedicel rounded-ovate, $1.3-1.5 \mathrm{X}$ as long as high, with short hairs; stylus mid-dorsal, $2.2 \mathrm{X}$ longer than antennomeres combined; distal segment of stylus with short hairs, somewhat elongated apically; length ratio of scape to pedicel (inner view) to postpedicel to stylus (segments 1 and 2), 0.08/0.13/0.25/ $0.16 / 0.59$; frons black, grey pollinose, nearly parallel-sided, $1.7 \mathrm{X}$ as wide as high, with distinct dot-like depression in middle of lower part; eyes finely haired; face densely white pollinose; ratio of height to width under antennae to width at clypeus, 0.54/0.27/0.13; clypeus small, slightly bulging; palpus small, yellow, with few black hairs and 1 black seta; proboscis short, brownish yellow, with yellow hairs; postocular setae mainly yellow, with 5 upper postoculars black.

Thorax. All setae black; pronotum pubescent, with black hairs; mesonotum black with bluish reflection, weakly grey pollinose; 6 dorsocentral setae, $8-10$ well developed acrostichals, biserial, almost reaching $5^{\text {th }}$ pair of dorsocentrals; pleura dark, with whitish grey pruinosity, in front of posterior spiracle bare; metapleuron bare; scutellum black with bluish reflection, with 2 strong medial setae and 2 short lateral setae.

Legs. Entirely yellow, hairs and setae black; coxae yellow; all tarsi simple; foreleg with coxa bearing numerous black hairs anteriorly and 5 strong black setae apically, fore femur with preapical posterior seta, fore tibia with 1 anterodorsal, 2 posterodorsal, 2-3 apical short setae, with anterodorsal comb-like row of setae distally, no long apicoventral seta; midleg with coxa bearing some black hairs and setae laterally and apically, mid femur with 1 strong anterior preapical seta and 1 strong posteroventral preapical seta, mid tibia with 3 anterodorsal, 2 posterodorsal, 1 anteroventral, 1 posteroventral and 5 apical bristles; hind leg with coxa bearing 1 strong seta at middle and 1 fine seta at apex, hind femur with 1 anterior preapical bristle at apical quarter, hind tibia with 3 anterodorsal, 3 posterodorsal, 3 apical bristles, row of 3-4 short ventral setae, densely covered with elongate setulae posteroventrally in distal half, with apical posteroventral comb of about 10 setulae; hind basitarsus (Figs 10-11)

Figs 8-17. Hercostomus spp., males: 8-16-H. yefremovae Grichanov, sp.n.; $17-$ H. thraciensis Kechev et Negrobov; 8 - habitus; 9 - head; 10 - apex of hind tibia and base of basitarsus, posterodorsal view; 11 - apex of hind tibia and hind basitarsus, lateral view; 12 wing; 13, 17 - hypopygium, lateral view; 14 - apicoventral epandrial lobe, hypandrium and phallus; 15 - surstylus; 16 - cercus.

Рис. 8-17. Hercostomus spp., самцы: 8-16-H. yefremovae Grichanov, sp.n.; 17 - H. thraciensis Kechev et Negrobov; 8 - внешний вид; 9 - голова; 10 - вершина задней голени и основание 1 -го членика лапки, сзади-сверху; $11-$ вершина задней голени и 1 -й членик задней лапки, сбоку; 12 - крыло; 13, 17 - гипопигий, сбоку; 14 - апиковентральная лопасть эпандрия, гипандрий и фаллус; 15 - сурстиль; 16 - церка. 

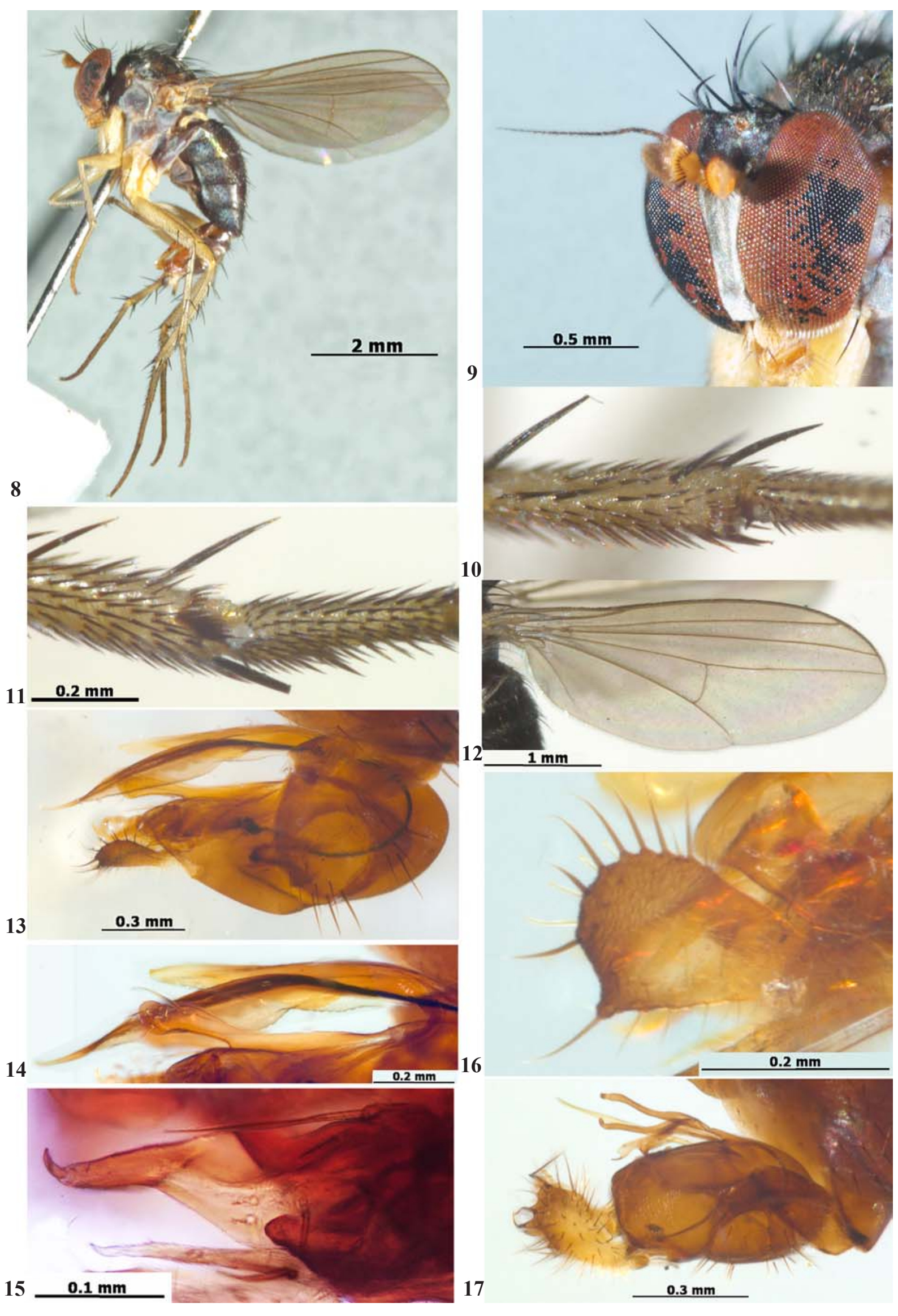

10
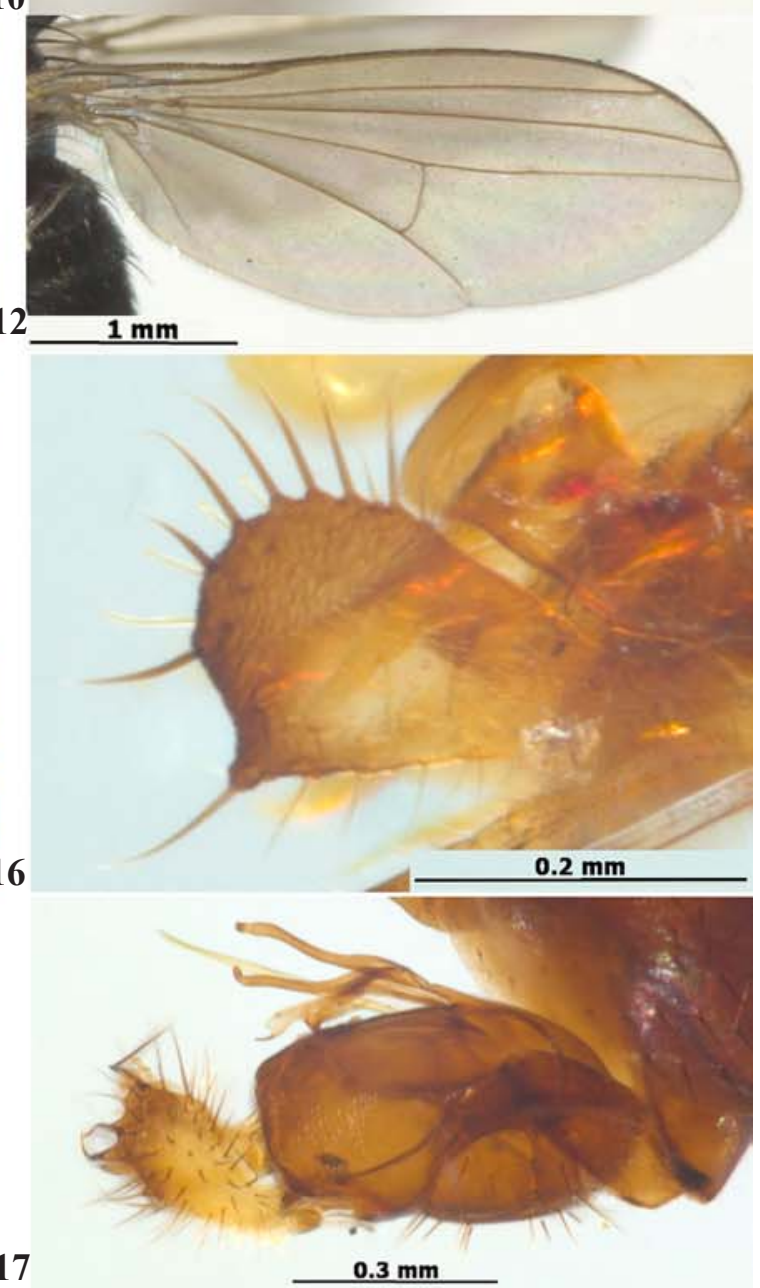
distinctly shorter than next tarsomere, with 3-4 short ventral setae, posterior bidenticulate or tridenticulate tooth basally. Tibia and tarsomere (from first to fifth) length ratio: fore leg: 106/44/21/15/11/13, mid leg: 137/76/42/32/19/16, hind leg: $168 / 48 / 58 / 42 / 27 / 16$

Wing (Fig. 12). 3 times longer than wide; membrane almost hyaline, veins brown; costa simple, with short black setae dorsally; $\mathrm{R}_{1}$ and $\mathrm{R}_{2+3}$ almost straight; $\mathrm{R}_{4+5}$ slightly convex anteriorly; $M_{1}$ almost straight in distal section; $R_{4+5}$ and $M_{1}$ subparallel in distal quarter of wing; $M$ joining costa at wing apex; ratio of costal section between $\mathrm{R}_{2+3}$ and $\mathrm{R}_{4+5}$ to that between $R_{4+5}$ and $M_{1}: 43 / 17$, distal part of $M_{4}^{2+3} 1.4 X$ longer than dm-m; anal vein distinct; anal angle obtuse; lower calypter yellow with black cilia; halter yellow.

Abdomen. Bluish-black and shiny dorsally, whitish grey pollinose laterally, with black hairs and long marginal setae; $6^{\text {th }}$ and $7^{\text {th }}$ segments black-brown, bare, $7^{\text {th }}$ segment with well developed tergum and sternum; $8^{\text {th }}$ segment pear-like, blackbrown, with black cilia dorsally.

Male genitalia (Figs 13-16). Epandrium brown-black, elongate-ovate, flattened basally, as long as terga 3-5 combined; appendages mainly yellow-brown; hypandrium (Fig. 14) mostly free, fused to epandrium at extreme base, smoothly curved, reaching apex of apicoventral epandrial lobe; phallus long, thin at apex and at base, broadened medially; basiventral epandrial lobes symmetrical, each lobe reduced to short seta at base of hypandrium; apicoventral epandrial lobe located rather distally, finger-like, slightly enlarged distally, bearing 2 setae at apex and 1 ventral seta at middle; anteroventral part of postgonite not developed; posterodorsal portion poorly developed, horn-like, slightly curved ventrally, swollen at base, with reduced lateral lobes; surstylus (Fig. 15) bilobed, with ventral lobe large and broad, strongly tapering at apex, with long basoventral seta and short apical seta; dorsal lobe thin and straight, acicular at apex, with 1 strong but short basodorsal seta; cercus (Fig. 16) mainly dirty yellow, broadly black along distal margin, elongate-ovate, expanded distally, with shallow emargination distodorsally, longer than high, $1 / 4^{\text {th }}$ epandrium length, with row of black marginal setae (except distodorsal emargination), with light cilia dorsally and ventrally, without modified setae.

Measurements. Body length 4.0-4.1 mm, antenna length $1.0 \mathrm{~mm}$, wing length $3.8-4.3 \mathrm{~mm}$, wing width $1.2 \mathrm{~mm}$.

Female. Similar to male except lacking male secondary sexual characters. Face wider than in male, $1.8 \mathrm{X}$ as wide as postpedicel, nearly parallel-sided; postpedicel as long as high. Measurements. Body length $4.0 \mathrm{~mm}$; wing length 4.0 $\mathrm{mm}$

ETYMOLOGY. The species is named after the Israeli and Russian entomologist Dr. Zoya A. Yefremova.

DIAGNOSIS. Face under antenna $1.7 \mathrm{X}$ as wide as postpedicel height; postpedicel rounded, $1.3-1.5 \mathrm{X}$ as long as high; arista-like stylus short-pubescent, $2.2 \mathrm{X}$ longer than antennomeres combined; wing almost hyaline; wing veins $\mathrm{R}_{4+5}$ and $\mathrm{M}_{1}$ slightly convergent, subparallel in distal quarter of wing; dm-m located right behind middle of wing; lower calypter with black setae; abdomen dark; hypopygium with cercus mainly dirty yellow, broadly black along distal margin, elongate-ovate, expanded distally, with shallow emargination distodorsally; hypandrium mostly free, fused to epandrium at extreme base, smoothly curved, reaching apex of apicoventral epandrial lobe; apicoventral epandrial lobe located rather distally, finger-like, slightly enlarged distally, bearing 2 setae at apex and 1 ventral seta at middle.

REMARKS. According to the old keys to the Palaearctic Hercostomus species, both $H$. kravchenkoi sp.n. nd $H$. yefre- movae sp.n. come to $H$. insularum from the traditional $1^{\text {st }}$ group of species (e.g. Negrobov et al., 2008), differing in face white pollinose rather than yellow-brown pollinose, distal part of $\mathrm{M}_{4}$ 5.5X (H. kravchenkoi sp.n.) or 1.4X (H. yefremovae sp.n.) rather than $2.2 \mathrm{X}$ (H. insularum) longer than $\mathrm{dm}-\mathrm{m}$, and in other morphological characters [see redescription of a type specimen by Rodionova, 2004]. H. insularum is known only from the Canary Islands. At the same time, H. kravchenkoi sp.n. is very close to $H$. cyprius Parent, 1937, known from Cyprus, and to H. tugajorum Stackelberg, 1949, known from Tajikistan, Kazakhstan and Uzbekistan, differing from the last two species in yellow ventrally abdominal terga, yellow segment 8, and morphology of hypopygium [see Parent, 1937: fig. 2; Stackelberg, 1949: figs 13, 31]. H. kravchenkoi sp.n. male has phallus with 2 short curved subapical teeth, which are absent in those two species. The three species have also somewhat different shape of male cercus. H. kravchenkoi sp.n., H. cyprius and H. tugajorum can form a subgroup of the Hercostomus plagiatus species group or even a separate group in the genus. The two new species can be distinguished from the closest species by use of the following key.

Key to West Palaearctic species of Hercostomus PlaGIATUS GROUP AND RELATED SPECIES (MALES)*

1. Mid femur with basoventral convexity bearing short black setae; body longer than $5 \mathrm{~mm}$................................... 2

- Mid femur without such basoventral convexity; body shorter than $4.5 \mathrm{~mm}$................................ 3

2. Antennal postpedicel pointed at apex; all coxae yellow; hypopygium not pinched posteriorly; $6.0 \mathrm{~mm}$...............

H. stroblianus Becker, 1917

- Antennal postpedicel truncated at apex; mid coxa blackish on outer side in basal half; hypopygium pinched posteriorly; $5.5 \mathrm{~mm}$............. H. libanicola Parent, 1993

3 Hypopygial cercus brown-black in at least distal half, whitish yellow to dark yellow basally....

- Hypopygial cercus entirely or mostly yellow, with more or less broad brown-black strip along distal margin ....... 6

4. Antennal postpedicel clearly acute, about $1.5 \mathrm{X}$ as long as high; wing veins $\mathrm{R}_{4+5}$ and $\mathrm{M}_{1}$ parallel along most of their length, slightly convergent near wing apex; hypopygium with club-shaped cercus bearing several small, yellow scale-like inner setae along distodorsal margin; apicoventral epandrial lobe bearing 3 setae apically on knob [Pollet, 1993: fig. 1] .......................... H. plagiatus (Loew, 1857)

- Antennal postpedicel subtriangular, about as long as high; wing veins $R_{4+5}$ and $M_{1}$ parallel along most of their length or distinctly convergent towards wing apex [Grichanov, 2015: figs 2, 3; Pollet, 1993: fig. 2]; hypopygium with ovoid or triangular cercus without scale-like setae; apicoventral epandrial lobe bearing 2 setae on its knob and 1 longer seta on stem .................................................. 5

5. Wing veins $R_{4+5}$ and $M_{1}$ parallel along most of their length, slightly convergent near wing apex; hypopygium with triangular cercus; epandrial lobe bearing very long seta at base of stem [Grichanov, 2015: figs 3, 5, 6] .................

\section{H. golanensis Grichanov, 2015}

- Wing veins $R_{4+5}$ and $M_{1}$ distinctly convergent towards wing apex; hypopygium with ovoid cercus; epandrial lobe bearing seta on stem right before knob [Pollet, 1993: fig. 2] ........................................ H. verbekei Pollet, 1993

6. Hypopygial cercus crescent or subtriangular, higher than long, entirely whitish-yellow ................................... 7

* H. stroblianus and H. libanicola are included in the key provisionally. 
- Hypopygial cercus rounded or elongate-ovate, expanded distally, black along distal margin ................................ 9

7. Lower calypter with yellow setae; abdomen entirely dark H. cyprius Parent, 1937

- Lower calypter with black setae; abdomen entirely dark or partly yellow ...................................................... 8

8. Abdomen including segment 8 green ............................ H. tugajorum Stackelberg, 1949

- Abdominal terga yellow ventrally; segment 8 yellow ... H. kravchenkoi sp.n.

9. Hypopygial cercus rounded with very narrow black margin ................................... H. convergens Loew, 1908

- Hypopygial cercus elongate-ovate, expanded distally, black along distal margin ............................................... 10

10. Face yellow-brown; wing vein $\mathrm{dm}$-m less than half as long as distal section of $\mathrm{M}_{4}$ [see Rodionova, 2004]

H. insularum Becker, 1917

- Face white; wing vein $\mathrm{dm}-\mathrm{m}$ more than half as long as distal section of $\mathrm{M}_{4}$

11. Distal sections of wing veins $\mathrm{R}_{4,5}$ and $\mathrm{M}_{1}$ slightly convergent, nearly parallel, $\mathrm{M}_{1}$ almost straight; $\mathrm{M}_{4} 1.3 \mathrm{X}$ longer than $\mathrm{dm}-\mathrm{m}$; mid coxa yellow; postpedicel $1.3-1.5 \mathrm{X}$ as long as deep ................................. H. yefremovae sp.n.

- Distal sections of wing $\mathrm{R}_{4+5}$ and $\mathrm{M}_{1}$ distinctly convergent, $\mathrm{M}_{1}$ with smooth but distinct bend; $\mathrm{M}_{4} 1.8 \mathrm{X}$ longer than $\mathrm{dm}-\mathrm{m}$; mid coxa with distinct brown spot on lateral surface; postpedicel 1.2X as long as deep ..

H. albicoxa Kazerani et al. , 2017

\section{New records}

\section{Hercostomus thraciensis Kechev et Negrobov} Fig. 17.

Hercostomus thraciensis Kechev, Negrobov, 2015: 200; Küçükberber et al., 2017: 25. Type locality: Bulgaria: Basha site, northwest of the Chirpan town.

MATERIAL. Israel: 10', Yakir [=Yaqqir], 4.IV.1981, F. Ka-

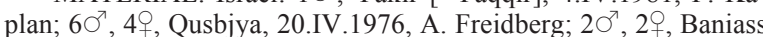
[=Panyas], 20.IV.1974, A. Freidberg; 1, Khashmiye [=Hushniya], 17.IV.1973, D. Furth; 10', Gonen, 15.III.1975, F. Kaplan (SMNH).

DISTRIBUTION. Bulgaria, Turkey. First record from Israel.

REMARKS. The species was originally referred to the Group II according to the old keys to the Palaearctic Hercostomus species [Kechev, Negrobov, 2015]; the last key to the Group II species [Negrobov et al., 2012] included at least two Hercostomus lineages, H. germanus (Wiedemann, 1817) and H. longiventris (Loew, 1857) in addition to Poecilobothrus armeniorum (Stackelberg, 1933). It was not clear from the original description and figures, which lineage $H$. thraciensis belonged to. We have examined the male genitalia of the species and found that it could be certainly associated with the $H$. longiventris lineage that is chiefly characterised by long thin basiventral epandrial lobes (Fig. 17).

\section{Condylostylus longicornis (Fabricius)} ica".

Musca longicornis Fabricius, 1775: 783. Type locality: “Amer-

Condylostylus longicornis (Fabricius, 1775); Becker, 1922: 283; Bickel, 2003: 552; Naglis, Bickel, 2017: 567, plate 1.

MATERIAL. $1 \sigma^{\top}$, Israel: Herzliyya, Hill, $32^{\circ} 11^{\prime} \mathrm{N} 34^{\circ} 49^{\prime} \mathrm{E}$, 11.IX.2016, A. Freidberg (SMNH).

DISTRIBUTION. Afrotropical: United Arab Emirates; Australasian: French Polynesia (Austral Is., Society Is., Marquesas, Tuamotu), USA (Hawaiian Is.); Nearctic: USA (California, Georgia, Florida, North Carolina), Bermuda, Mexico;
Neotropical: Mexico, Panama, Brazil, Peru, Bolivia, Dominica, Ecuador, Argentina, Chile, Galapagos Islands [Naglis, Bickel, 2017]. First record from the Palaearctic Region.

REMARKS. The genus was not known in the West Palaearctic. C. longicornis is a typical representative of the New World Condylostylus (see Bickel [2003]), having no relatives in the afrotropical fauna (see Grichanov [2010]). It was only recently found in the Southern part of the Arabian Peninsula [Naglis, Bickel, 2017; Grichanov, unpublished], and Naglis and Bickel [2017] suggested that this occurrence was most probably the result of accidental human introduction.

\section{Conclusion}

Species of the $H$. plagiatus group occur mainly in the West Palaearctic countries with mild climate, from UK, Belgium and the Netherlands in the North, to North Africa in the South and to Central Asia in the East. Hercostomus convergens is widespread in the Southern Palaearctic, from France and Spain to Azerbaijan and Iran. H. plagiatus extends its range from West Europe to the Balkan countries in the East. H. tugajorum is sparsely distributed in the Central Asia. The other Palaearctic species of the group are rarely collected, being recorded usually from some local regions. Hercostomus kravchenkoi sp.n., $H$. yefremovae sp.n. and $H$. golanensis are known only from Israel in the East Mediterranean. The common habitats for adults of $H$. plagiatus and $H$. verbekei in Europe are humid woodlands, riverbanks and marshlands [see Pollet, 1993 for the detailed description of habitat preference and phenology of Belgian species].

The most comprehensive review of long-legged flies from Israel was published by Grichanov [2017b], who listed 108 species. This paper presents the new material on Dolichopodidae from the country. With the new species described and recorded here, the Israeli fauna of the family now totals 112 recognized species.

ACKNOWLEDGMENTS. The authors are sincerely grateful to Leonid Friedman (SMNH) for helping us with the spelling of localities. An anonymous reviewer kindly commented on earlier drafts of the manuscript. The work of IYG is performed within the Program for Basic Scientific Researches in the Russian Federation for the Long-Term Period (2013-2020) approved by Order No. 2538-r of the Government of the Russian Federation dated 27 December 2012.

\section{References}

Becker Th. 1922. Dipterologische Studien. Dolichopodidae der Indo-Australischen Region // Capita Zoologica. Vol.1. No.4. P.1-247.

Bernasconi M.V., Pollet M., VarinI-Oojen M., Ward P.I. 2007. Molecular systematics of Dolichopodidae (Diptera) inferred from COI and 12S rDNA gene sequences based on European exemplars // Invertebrate Systematics. Vol.21. No.5. P.453470.

Bickel D.J. 2003. New synonyms in the Nearctic and Neotropical Sciapodinae (Diptera: Dolichopodidae) // Studia dipterologica. Vol.9. P.545-560. 
Fabricius J.C. 1775. Systema entomologiae, sistens insectorum classes, ordines, genera, species adiectis synonymis, locis, de scriptionibus, observationibus. Flensburgi et Lipsiae [= Flensburg and Leipzig]: Korte. P.1-832.

Grichanov I.Ya. 2010. A new species of Condylostylus Bigot, 1859 (Diptera: Dolichopodidae) from Tanzania and a new generic synonym // Far Eastern Entomologist. No.216. P.1-10.

Grichanov I.Ya. 2015. Palaearctic species of the Hercostomus plagiatus group (Diptera: Dolichopodidae) with description of a new species from the Middle East // Zootaxa.Vol.3918. No.3. P.424-432.

Grichanov I.Ya. 2017a. Alphabetic list of generic and specific names of predatory flies of the epifamily Dolichopodoidae (Diptera). 2nd Edition. St.Petersburg: VIZR. P.1-563 (Plant Protection News Supplements, N23). Available from: https://archive.org/ download/Grichanov2017DolibankSec/Grichanov\%202017\% 20Dolibank-sec.pdf (accessed 30 May 2018).

Grichanov I.Ya. 2017b. An annotated checklist of Dolichopodidae (Diptera) of Israel and adjacent territories // Acta Biologica Sibirica. Vol.3. No.4. P.6-19.

Grichanov I.Ya., Brooks S.E. 2017. 56. Dolichopodidae (longlegged dance flies) // Kirk-Spriggs A.H., Sinclair B.J. (eds.). Manual of Afrotropical Diptera. Vol.2. Nematocerous Diptera and lower Brachycera. Suricata 5. Pretoria: SANBI Graphics and Editing. P.1265-1320.

Kazerani F., Khaghaninia S., Talebi A.A., Persson M., Pollet M. 2017. Eight new species of Dolichopodinae (Diptera: Dolichopodidae) from northern Iran // Zootaxa. Vol.4242. No.1. P.111-141.

Kechev M., Negrobov O. 2015. A New Species of the Genus Hercostomus Loew, 1857 (Diptera: Dolichopodidae) from Bulgaria // Acta Zoologica Bulgarica. Vol.67. No.2. P.199-202.

Küçükberber M., Tonguç A., Koç H. 2017. Dolichopodidae (Diptera) fauna of Spil Mountain with four new records // Turkish Bulletin of Entomology. Vol.7. No.1. P.23-29.

Naglis S., Bartak M. 2015. Dolichopodidae (Diptera) from the Iberian Peninsula, with description of three new species // Zootaxa. Vol.3964. No.1. P.125-137.

Naglis S., Bickel D.J. 2017. Order Diptera, Family Dolichopodidae Subfamily Sciapodinae // Arthropod fauna of the UAE. Vol.6. P.565-571.

Naglis S., Negrobov O.P. 2017. West Palaearctic species of the Hercostomus species-group III (Diptera, Dolichopodidae), with description of a new species from Turkey // Alpine Entomology. No.1. P.33-38.

Negrobov O.P., Nechay N.A., Maslova O.O. 2008. Key to the Palearctic species of the genus Hercostomus Loew (Diptera Dolichopodidae). Part $1 / /$ International Journal Dipterological Research. Vol.19. No.4. P.187-191.
Negrobov O.P., Nechay N.A. 2009a. Key to the Palearctic species of the genus Hercostomus Loew (Diptera, Dolichopodidae). Part 5 // International Journal Dipterological Research. Vol.20. No.4. P.201-206.

Negrobov O.P., Nechay N.A. 2009b. [New species of the genus Hercostomus Loew, 1857 (Diptera, Dolichopodidae) with a key of Palearctic species of the IV group] // Byulleten Moskovskogo Obshchestva Ispytatelei Prirody. Otdel biologicheskii. Vol.114. No.5. P.84-87 [in Russian].

Negrobov O.P., Nechay N.A., Selivanova O.V., Maslova O.O. 2012. Key to the Palearctic species of the genus Hercostomus Loew (Diptera, Dolichopodidae). Part 2 // International Journal Dipterological Research. Vol.23. No.2. P.83-88.

Negrobov O.P., Maslova O.O., Selivanova O.V. 2016. [New species of Hercostomus Loew, 1857 (Diptera: Dolichopodidae) from Tajikistan] // Caucasian Entomological Bulletin. Vol.12. No.1. P.175-177 [in Russian].

Negrobov O.P., Nechay N.A., Maslova O.O. 2008. Key to the Palaearctic species of the genus Hercostomus Loew (Diptera, Dolichopodidae). Part $1 / /$ International Journal Dipterological Research. Vol.19. No.4. P.187-191.

Parent O. 1937. Diptères Dolichopodidés espèces et localités nouvelles // Bulletin et Annales de la Société entomologique de Belgique. T.77. P.125-148.

Pollet M. 1993. Morphological and ecological characterization of Hercostomus (Hercostomus) plagiatus and a sibling species, $H$. verbekei sp.n. (Diptera: Dolichopodidae) // Zoologica Scripta. Vol.22. No.1. P.101-109.

Pollet M., Germann C., Tanner S., Bernasconi M.V. 2010. Hypotheses from mitochondrial DNA: congruence and conflict between DNA sequences and morphology in Dolichopodinae systematics (Diptera: Dolichopodidae)//Invertebrate Systematics. Vol.24. No.1. P.32-50.

Rodionova S.Yu. 2004. [Review of subfamily Dolichopodinae (Dolichopodidae, Diptera) of Russia and adjacent territories]. PhD Thesis. Voronezh: Voronezh University. 253 pp [In Russian]

Selivanova O.V., Negrobov O.P., Nechay N.A., Maslova O.O. 2012. Key to the Palearctic species of the genus Hercostomus Loew (Diptera, Dolichopodidae). Part 3 // Cesa News. No.78. P.1-6.

Stackelberg A.A. 1949. [Species of the genus Hercostomus Lw. (Diptera, Dolichopodidae) of middle Asiatic Fauna] // Trudy Zoologicheskogo Instituta. AN SSSR. Vol.8. No.4. P.669-687 [in Russian, with English summary].

Tonguç A., Grootaert P., Barlas M. 2016. A new species of Hercostomus Loew, 1857 (Diptera: Dolichopodidae) from Turkey // Zoology in the Middle East. Vol.62. No.4. P.363-366. 